\title{
The Linebarger Site on Dry Creek, Camp County, Texas
}

Timothy K. Perttula

Heritage Research Center, Stephen F. Austin State University

Follow this and additional works at: https://scholarworks.sfasu.edu/ita

Part of the American Material Culture Commons, Archaeological Anthropology Commons, Environmental Studies Commons, Other American Studies Commons, Other Arts and Humanities Commons, Other History of Art, Architecture, and Archaeology Commons, and the United States History Commons

Tell us how this article helped you.

This Article is brought to you for free and open access by the Center for Regional Heritage Research at SFA ScholarWorks. It has been accepted for inclusion in Index of Texas Archaeology: Open Access Gray Literature from the Lone Star State by an authorized editor of SFA ScholarWorks. For more information, please contact cdsscholarworks@sfasu.edu. 


\section{The Linebarger Site on Dry Creek, Camp County, Texas \\ Creative Commons License \\ (c) (1) \& 8}

This work is licensed under a Creative Commons Attribution-NonCommercial 4.0 International License 


\title{
The Linebarger Site on Dry Creek, Camp County, Texas
}

\author{
Timothy K. Perttula
}

\section{INTRODUCTION}

The Linebarger site (41CP493) is an ancestral Caddo site on Dry Creek in Camp County (see Perttula et al. 2010:Figure 6), not far upstream from the Tuck Carpenter site and large Late Caddo Titus phase cemetery (Turner 1978, 1992). At least four ancestral Caddo burials are known to have been excavated at the Linebarger site in the 1960s, and Perttula et al. (2010:Figures 306-307) documented two vessels and a large chipped biface from burial contexts in the Tommy Johns collection. The Robert L. Turner. Jr, surface collection came from an unspecified habitation area at the site.

The first documented vessel was a small inverted rim carinated bowl with a typologically unidentified engraved motif (horizontal engraved rim panel with a series of unique elements, including vertical engraved lines, ovals, semi-circles, and diagonal engraved lines, without apparent rhyme or pattern), and the other was a small tool punctated jar with rim peaks and lug handles. The biface, made from a dark grayish-brown Central Texas chert, was well knapped with small retouch/pressure flakes along both edges of the piece; there is no evidence of polish on either face. The biface has basal notches and a short expanding stem $(20.8 \mathrm{~mm}$ in stem width and $11.8 \mathrm{~mm}$ in stem length). The biface is $174.5 \mathrm{~mm}$ in length, $72.0 \mathrm{~mm}$ in width, and only $7.6 \mathrm{~mm}$ in thickness.

\section{LITHIC ARTIFACTS}

The lithic artifacts in the Linebarger site collection include one quartzite fire-cracked rock, 13 pieces of lithic debris, and two chipped stone tools. The chipped stone tools include an end scraper made from a nonlocal dark grayish-brown chert and a dart point (i.e., Gary point) preform made on a heat-treated local quartzite.

The lithic debris is from the manufacture of chipped stone tools made from both local and non-local raw materials. The local materials (primarily from stream gravels in the Big Cypress Creek basin) include heattreated and non-heat-treated quartzite $(n=6)$, yellow chert $(n=1)$, and red chert $(n=1)$. Non-local lithic raw materials, from Red River gravels and/or Ouachita Mountains sources in southeastern Oklahoma, include red jasper $(n=2)$, gray novaculite $(n=1)$, siliceous shale $(n=1)$, and dark gray chert $(n=1)$.

\section{CERAMIC ARTIFACTS}

The Turner collection from the Linebarger site has 85 vessel sherds and a rim from an elbow pipe. The vessel sherds are divided into 42 plain ( 10 base and 32 body sherds) and 43 decorated sherds; the plain to decorated sherd ratio is 0.98 . Approximately $90 \%$ of the sherds are from grogtempered vessels and the remainder are from bone-tempered vessels,

Fine ware sherds comprise $30 \%$ of the decorated sherds. Two are interior/exterior red-slipped bowl or carinated bowl sherds (Figure 1a-b). The rim sherd has a rim peak and an interior thickened profile (Figurc $1 b$ ). The remainder are sherds

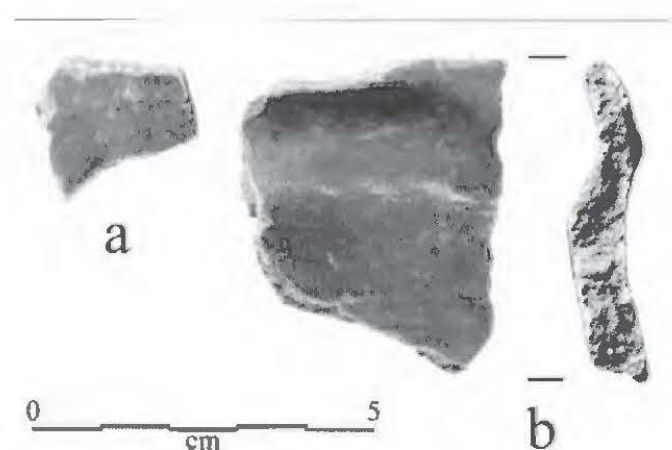

Figure 1. Red-slipped rim and body sherds. 


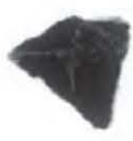

a

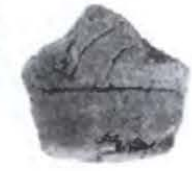

b
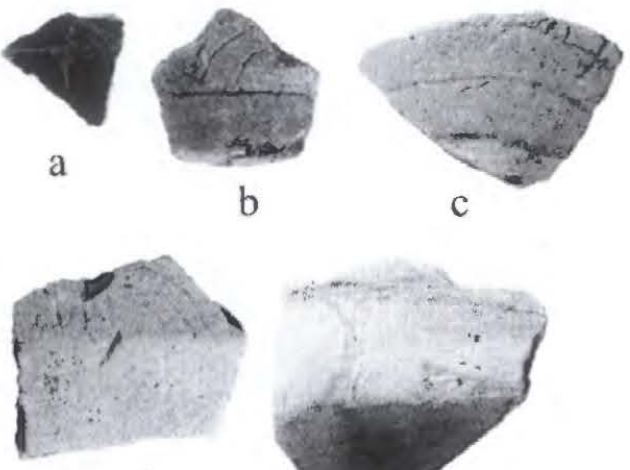

d
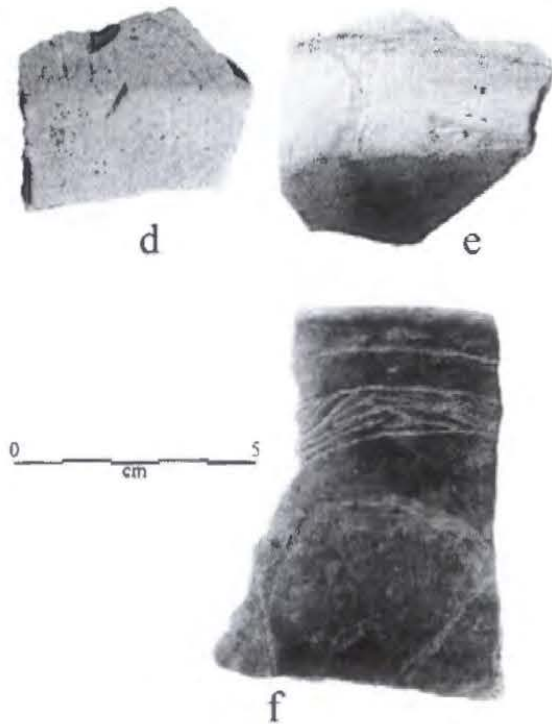

Figure 2. Engraved bottle and carinated bowl sherds: a, c, bottle sherds; b, d-f, carinated bowl sherds.

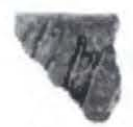

a

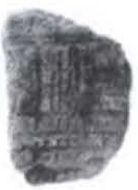

b

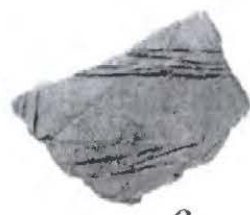

C

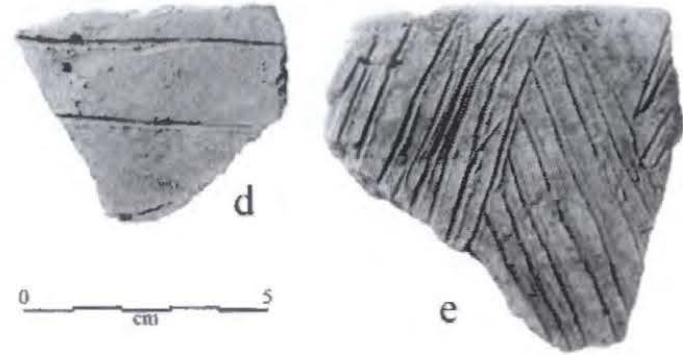

Figure 3. Incised rim and body sherds: a, diagonal incised rim; b, overlapping incised body sherd; c, opposed incised body sherd; d, widely-spaced parallel incised body sherd; e, opposed incised rim sherd. from engraved bottles (Figure 2a, c) and carinated bowls (Figure 2b, d-f).

Two of the engraved sherds are from bottles (see Figure 2a, c). These have straight lines and spurs or curvilinear engraved lines; one bottle sherd has a red pigment rubbed in the engraved lines (see Figure 2a). Carinated bowl sherds have concentric semi-circular and/or diagonal motifs (see Figure $2 b, d, f, n=3$ ), semicircular and vertical engraved lines with spurs $(n=1)$, slanted scrolls (cf. Ripley Engraved, see Figure 2e, $n=1$ ), nested triangles (cf. Ripley Engraved, var. Cash or var. Williams, $n=1$ ), and horizontal engraved lines $(n=3)$, including two rims with a horizontal engraved line under the lip. These rims have a direct profile and rounded, exterior folded lips.

The incised sherds $(n=10,23 \%$ of the decorated sherds and $33 \%$ of the utility wares) include two rims and eight body sherds. One rim has diagonal incised lines (Figure 3a), while the other, probably from a Maydelle Incised jar (Figure 3e), has diagonal opposed incised triangles. Incised elements on the body sherds include parallel lines ( $n=5$, Figure $3 d$ ), opposed incised lines $(n=2$, Figure $3 c)$, and overlapping incised lines $(n=1$, Figure $3 b)$.

Eight sherds have brushed decorations (18.6\% of the decorated sherds and $26.7 \%$ of the utility wares). Five have parallel brushing marks (Figure 4b-c, e) likely oriented vertically on jar bodies), one has opposed brushing marks (Figure 4d), and another has vertical brushing marks. Another body sherd, possibly from a Pease
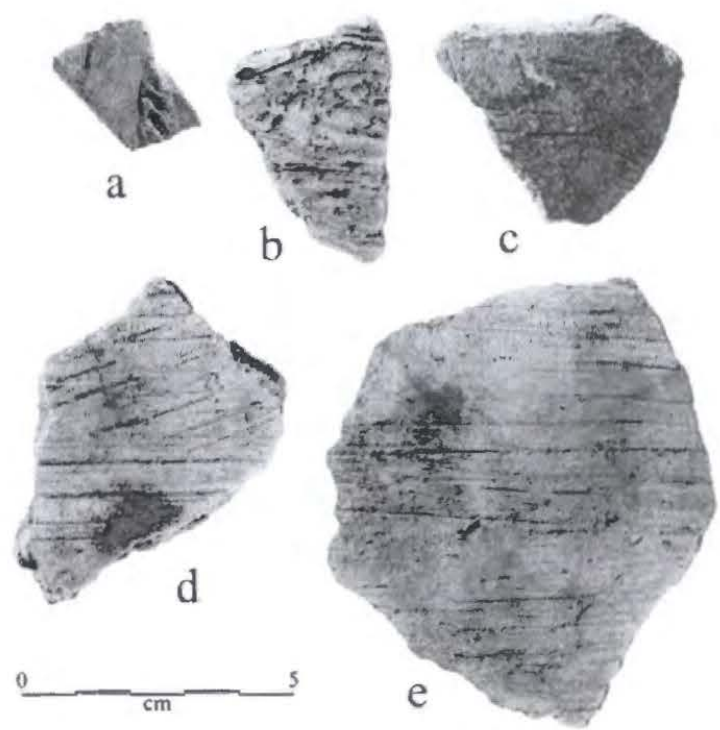

Figure 4. Brushed and brushed-punetated-appliqued body sherds: a, brushedpunctated-appliqued; b-c, e, parallel brushed; d, opposed brushed. 

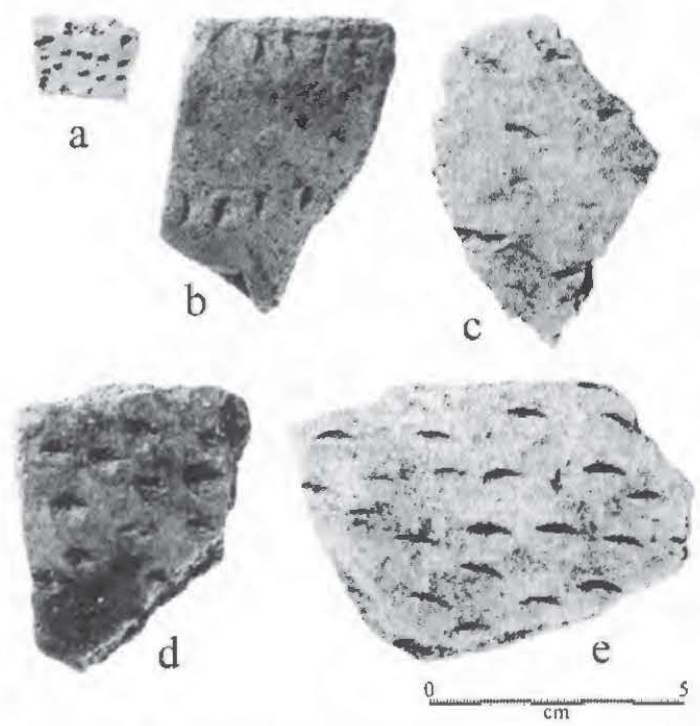

Figure 5. Punctated body sherds: a, closely-spaced tool punctated; $b$, widely-spaced tool punctated; $c-d$, tool punctated; e, fingernail punctated.
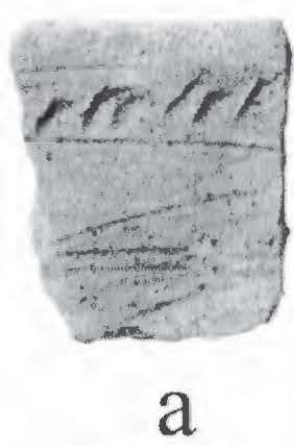

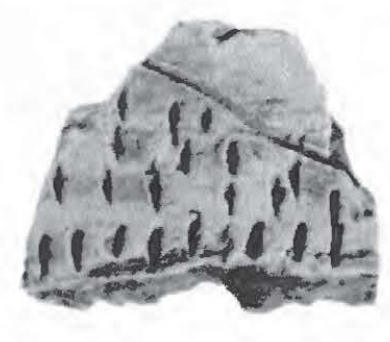

b

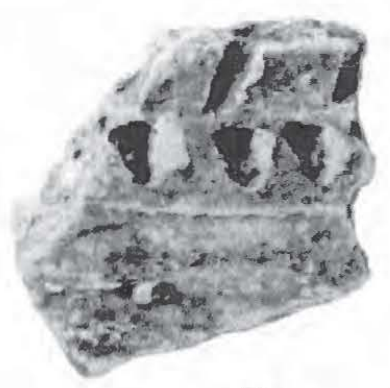

$\mathrm{C}$

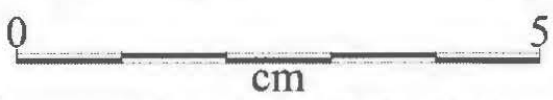

Figure 6. Incised-punctated rim and body sherds: a, horizontal incised-tool punctated row rim sherd; $b$, tool punctated-filled incised triangle body sherd; $c$, tool punctated rows and parallel incised body sherd.

Brushed-Incised vessel, has parallel brushing marks, tool punctates pushed through one area of brushing, and a straight appliqued fillet (Figure 4a).

There are eight punctated body sherds (I8.6\% of the decorated sherds and $26.7 \%$ of the utility wares), six with tool punctates (Figure 5a-d) and two with fingernail punctates (Figure 5e). The punctations occur in continuous horizontal rows across the vessel surface, likely on both the rim and portions of the bodies of jars.

The four incised-punctated sherds $(9.3 \%$ of the decorated sherds and $13.3 \%$ of the utility wares) have two distinct motif elements: (1) tool punctated rows and horizontal/parallel incised lines either above or below the punctations ( $n=2$, Figure $6 a, c)$, and (2) incised triangles filled with linear or circular tool punctations ( $\mathrm{n}=2$, Figure $6 \mathrm{~b}$ ).

There also is a post-A.D. 1350-1450 elbow pipe rim sherd in the collection. It is grog-tempered, and has a direct rim and a flat lip. 


\section{MISCELI.ANEOUS ARTIFAC'TS}

Miscellaneous artifacts in the Turner collection from the Linebarger site include an unburned deer bone and a single piece of daub.

\section{CONCLUSIONS}

The small surface collection obtained by Robert L. Turner, Jr. from the Linebarger site includes 16 lithic artifacts, 85 vessel sherds, one elbow pipe rim sherd, a deer bone, and a piece of daub. The vast majority of these artifacts are likely from ancestral Caddo habitation deposits associated with a cemetery of unknown size. The one Gary point preform suggests a very limited use of the site sometime in the Woodland period.

The decorated vessel sherds from the site include a range of sherds from both fine ware bottles and utility ware jars. Several of the engraved carinated bowl sherds have decorative clements and motifs consistent with ca. $14^{\text {th }}$ and $15^{\text {th }}$ century Caddo wares in the Big Cypress Creek basin, including several sherds comparable to defined varicties of Ripley Engraved. However, the common occurrence of red-slipped sherds ( $4.7 \%$ of the decorated sherds) and only a moderate quantity of brushed sherds (18.6\%), including a possible Pease Brushed-Incised sherd, are similar to nearby Middle Caddo components at sites such as Harold Williams (41CPI0, Turner and Smith 2003) and Polk Estates (41CP245, Nelson and Perttula 2006) that have radiocarbon dates that range from A.D. 1300-1460 and OCR dates that range from A.D. 1191-1410. Thus, the Linebarger site likely is contemporancous with these ancestral Caddo sites in the middle reaches of the Big Cypress Creek basin.

\section{REFERENCES CITED}

Nelson, B. and T. K. Perttula

2006 Archaeological Investigations at the Polk Estates Site (41CP245), Camp County, Texas. Journal of Northeast Texas Archaeology 24:1-83.

Perttula, T. K., M. Walters, and B. Nelson

2010 Caddo Pottery Vessels and Pipes from Sites in the Big Cypress, Sulphur, Neches-Angelina, und Middle Sabine River Basins in the Turner and Johns Collections, Camp, Cass, Cherokee, Harrison, Morris, Titus, and Upshur Counties, Texas and Sabine Parish, Louisiana. Special Publication No. 10. Friends of Northeast Texas Archaeology, Pittsburg and Austin.

Turner, R. L.

1978 The Tuck Carpenter Site and Its Relations to Other Sites within the Titus Focus. Bulletin of the Texas Archeological Society 49:1-110.

1992 Prehistoric Mortuary Remains at the Tuck Carpenter Site, Camp County, Texas. Studies in Archeology No. 10. Texas Archeological Research Laboratory, The University of Texas at Austin.

Turner, R. L., and J. E. Smith II

2003 The Harold Williams Site (41CP10) and the Texas Archeological Society Field School of 1967. Bulletin of the Texas Archeolngical Society 73:1-68. 